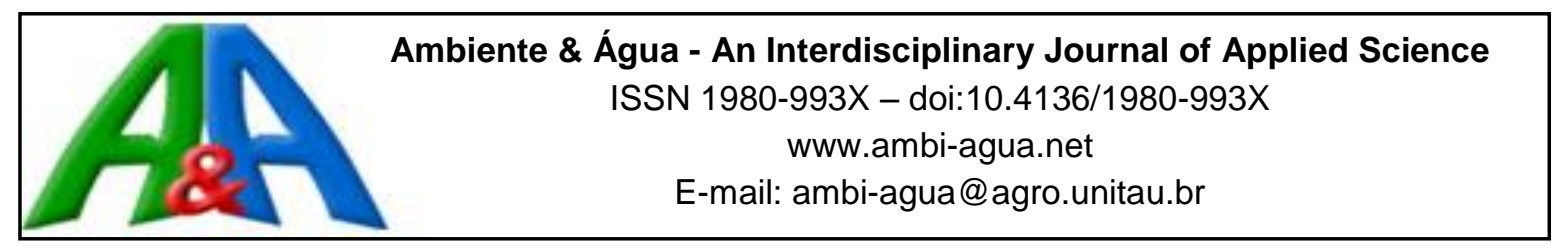

\title{
Adsorption of cadmium in vegetable sponge (Luffa cylindrica)
}

\author{
doi: 10.4136/ambi-agua.1340 \\ Received: 11 Mar. 2014; Accepted: 29 May 2014

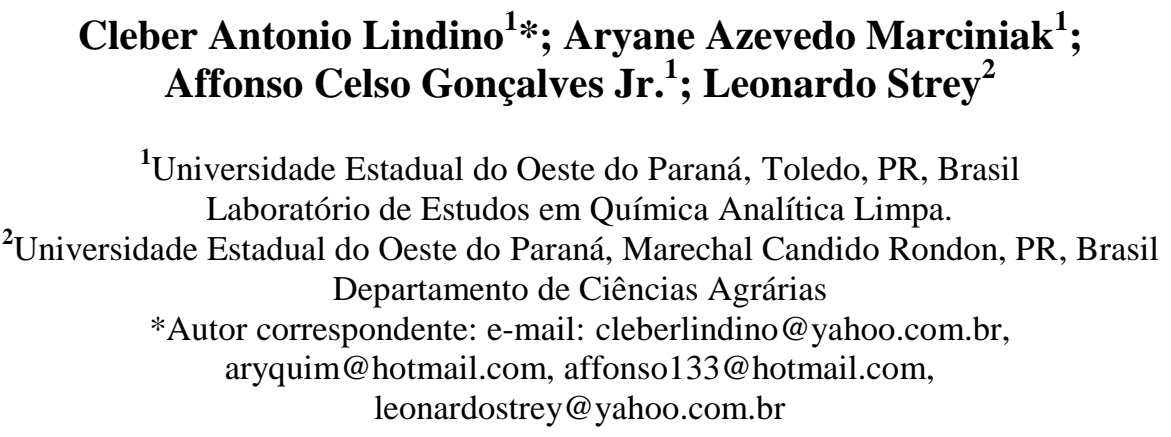

\begin{abstract}
The use of biomass as an adsorbent material follows the principles of sustainability and Green Chemistry. Given the low cost, high abundance, easy availability and high adsorption capacity of the vegetable sponge (Luffa cylindrica), this study aimed to explore the adsorption process of the toxic metal cadmium $(\mathrm{Cd})$. The parameters evaluated were $\mathrm{pH}$, contact time, adsorption isotherms, thermodynamic parameters, percolation and desorption. The proposed method showed high retention of Cd ions, being $99.80 \%$ at $\mathrm{pH} 5.0$ for the percolation method, more effective than with stirring, which had $89.6 \%$. It is noteworthy that the vegetable sponge adsorbs significant amounts of $\mathrm{Cd}$ in the range of $\mathrm{pH} 4.0$ to 6.0, indicating that is not necessary to adjust $\mathrm{pH}$ for most treatments in real samples. The $\mathrm{Cd}$ ion is spontaneous and favorably adsorbed by this material, according to the Freundlich isotherm model. According to the obtained results, it is feasible to use vegetable sponge as a material for the remediation of effluents due to high retention of Cd ions.
\end{abstract}

Keywords: green chemistry, sustainability, toxic metal.

\section{Adsorção de cádmio em esponja vegetal (Luffa cylindrica)}

\section{RESUMO}

O uso da biomassa como material adsorvente segue os princípios da sustentabilidade e da Química Verde. O presente trabalho teve como objetivo estudar o processo de adsorção de cádmio (Cd) em esponja vegetal (Luffa cylindrica), em função de seu baixo custo, alta abundância, fácil disponibilidade e alta capacidade de adsorção. Neste estudo foram avaliados o pH, o tempo de contato, as isotermas de adsorção, os parâmetros termodinâmicos, a percolação e a dessorção. O método proposto mostrou elevada taxa de retenção de íons $\mathrm{Cd}$ na superfície da esponja vegetal, sendo de $99,80 \%$ a um pH de 5,0 para o método de percolação que foi mais eficaz do que por agitação com 89,6 \% de adsorção. A esponja vegetal adsorve quantidades significativas de $\mathrm{Cd}$ no intervalo de $\mathrm{pH}$ de 4,0 a 6,0, o que indica não ser necessário ajustar o pH para a maioria dos tratamentos em amostras reais. De acordo com o modelo de isoterma de Freundlich, a adsorção do íon Cd no material adsorvente estudado é 
favorável e espontânea, sugerindo o emprego da esponja vegetal Luffa cylindrica como uma opção interessante para a recuperação de efluentes devido à sua elevada capacidade de retenção de íons $\mathrm{Cd}$.

Palavras-chave: química verde, sustentabilidade, metal tóxico.

\section{INTRODUCTION}

One of the main environmental issues today is related to water contamination by effluents and potentially toxic metals and their cumulative effects on biota (Monteiro and Mainier, 2010).

The industries that release tailings into rivers and sewers without proper treatment are responsible for the majority of soil and water contamination with potentially toxic metals, threatening biodiversity.

There are rules established by environmental entities such as the US Environmental Protection Agency (USEPA) and the National Council for the Environment (Brasil, 2005; 2011; USEPA, 2009) that set maximum values for potentially toxic metals in effluents. Due to these rules, industries should provide proper treatment of waste before discharging it, determining the specific treatment for each residue.

Among these metals, cadmium (Cd) is considered a highly dangerous metal, toxic even at low levels and, when ingested or inhaled, provokes serious diseases, especially in the kidneys and bones (Rodrigues et al., 2006). It is classified as a carcinogenic element.

One of the processes for the removal of toxic metals in liquid residues is adsorption, whose efficacy is directly related to the type of absorbent employed (Arruda and Tarley, 2003; Tran et al., 1999).

Through the application of physicochemical models, adsorption interactions between the adsorbed species and the adsorbent material are studied. The relationship between the amount of a metal ion adsorbed in the solid phase $(\theta)$ and its concentration in solution is quantified by an isotherm $(\phi / \mathrm{C}$ ratio) which allows us to know the type of adsorption. Different adsorption models are used to quantify the effect, such as the Langmuir and Freundlich models (Salehizadeh and Shojaosadati, 2003).

The Langmuir isotherm model assumes that all the forces that act on the adsorption are similar in nature to those that involve a chemical reaction, and that the adsorption comes to be a single layer of molecules on the surface of solid particles (Tagliaferro et al., 2011).

The Freundlich model is an empiric equation that considers a multilayer structure; it does not predict the saturation of the surface and it refers to the adsorbent surface as heterogeneous. It is applied to characterize the multiple types of adsorptive sites, which possess different adsorptive characteristics (Gonçalves Junior et al., 2012).

Adsorption with activated charcoal, for example, is cited by the Environmental Protection Agency as one of the best technologies for the control of pollutants. However, its utilization is restricted due to its high cost (Volesky, 2001).

Nevertheless, low cost materials like biomass are used on the adsorption of metals, including algae, microorganisms, compound materials and lignocelluloses, such as sugar cane bagasse, peanut, soybean and cotton crust. The use of biomass as adsorbent material is in agreement with the sustainability principle and the Green Chemistry.

The main concern of Green Chemistry is the development of new non-pollutants and non-environmental damaging technologies and processes. The application of Green Chemistry principles leads to regulation and control in order to avoid unnecessary remediation. Besides the environmental benefits, such thinking also considerably reduces 
economic impact, due to decreased spending on decontamination and the payment of indemnities (Prado, 2003).

However, in contaminated environments or in productive systems in which the minimization of residues is not yet possible, remediation aimed at lowering the impact of the contaminants is a necessity. The vegetable sponge (Luffa cylindrica) is a natural, low cost, non-toxic, biodegradable and abundant material. Its growth rate is about 8,000 units per hectare in tropical countries such as Brazil, and production can reach 100,000 dozens per year in a single production region.

Since the sponge has lignocellulosic material in its structure, it also contains lignin, cellulose and hemicellulose, all of them with adsorptive sites, like carbonyl, carboxyl, amine and hydroxyl groups, capable of adsorbing metal ions by interactions such as ionic exchange or complexation. On average, the natural sponge has $82.5 \%$ total cellulose and $11.6 \%$ lignin (Tanobe et al., 2002). This factor combined with the porosity of the vegetable sponge has attracted studies on the processes of adsorption.

Diverse studies have explored the use of $L$. cylindrica as an adsorbent for removal of cationic surfactants (Ye et al., 2013), acetaminophen (Ribeiro et al., 2011), dyes (Demir et al., 2008; Altinisik et al., 2010), textile dyes (Oliveira et al., 2011) and phenol (Henini et al., 2012).

In relation to potentially toxic metals, it was verified that $L$. cylindrica can be used in the removal of copper ions from natural waters (Laidani et al., 2011). The use of natural sponge was investigated for the adsorption of lead $(\mathrm{Pb})$ and it was verified that maximum capacity of $\mathrm{Pb}$ adsorption was $9.20 \mathrm{mg} \mathrm{g}^{-1}$; in the percolation of a lab effluent, more than $98 \%$ of the lead was adsorbed, presenting a concentration $\left(0.17 \mathrm{mg} \mathrm{L}^{-1}\right)$ below the maximum limit allowed by Brazilian law (0.5 $\left.\mathrm{mg} \mathrm{L}^{-1}\right)$ (Arruda and Tarley, 2003)

This work proposed a methodology that uses a low cost, natural, easily obtained and abundant material with the purpose of evaluating its applicability as an adsorbent for the metal Cd.

\section{MATERIAL AND METHODS}

Natural sponge purchased at the local market was oven-dried at $90 \pm 1{ }^{\circ} \mathrm{C}$ during $24 \mathrm{~h}$, homogenized and ground in a Wiley knife mill (Marconi MA 048) to an average $2 \mathrm{~mm}$ particle size.

For the adsorption tests, $50 \mathrm{mg}$ of sponge was used and $50.00 \mathrm{~mL}$ of $\mathrm{Cd}\left(\mathrm{NO}_{3}\right)_{2}$ (Biotec) at $25 \mathrm{mg} \mathrm{L}^{-1}$ (Biotec). The $\mathrm{pH}$ was adjusted with the addition of $\mathrm{HCl}$ (Vetec 37\%) and $\mathrm{NaOH}$ (Vetec 99\%) $0.01 \mathrm{~mol} \mathrm{~L}^{-1}$ to $\mathrm{pH}$ 2.0, 4.0, 5.0 and 6.0 measured with a $\mathrm{pH}$ meter (Lutron). Tests were performed in triplicate.

Each solution was stirred using a magnetic stirrer (SL90 Solab) at times of 10, 20, 30, 40 and 50 minutes and $10 \mathrm{~mL}$ of supernatant was drawn at each time interval and stored in different vials. The $\mathrm{Cd}$ was determined by flame atomic absorption spectrometry AAS (GBC 932 AA).

The adsorbent material was characterized morphologically in a scanning electron microscope FEI Quanta 200, with an operating voltage of $30 \mathrm{kV}$. The sample was placed on the double-sided tape attached to a carbon support and this was metalized with gold to a thickness of about $30 \mathrm{~nm}$ by using a sputter coater Baltec Scutter SCD 050.

Also, characterization was carried out by Infrared Spectrophotometry in the region between 4000 and $500 \mathrm{~cm}^{-1}$, by the technique of potassium bromide pellets $(\mathrm{KBr})$ on a device Bomem MB - 102 Fourier transform with resolution of $4 \mathrm{~cm}^{-1}$.

To study the isotherms, $500 \mathrm{mg}$ of sponge (adsorbent material) and $50 \mathrm{~mL}$ of a solution of $\mathrm{Cd}$ at $\mathrm{pH} 5.0$ at different concentrations: 10, 20, 30, 40, 50, 60, 70, 80 and $90 \mathrm{mg} \mathrm{L}^{-1}$ were 
placed in $125 \mathrm{~mL}$ Erlenmeyer flasks. The solutions were stirred on a stirrer (141 Marconi MA) for 3 hours at $200 \mathrm{rpm}$ at $25^{\circ} \mathrm{C}$. Samples were then filtered and a $10 \mathrm{~mL}$ aliquot of each solution was drawn to determine Cd by AAS (flame) using a certified standard curve (Welz and Sperling, 1999). Tests were performed in triplicate.

With the data of initial and final concentrations of the solutions containing $\mathrm{Cd}$ before and after the adsorption process, it was possible to determine the amount of adsorbed metal for each solution using Equation 1 (Salvado et al., 2012).

$$
q=\frac{\left(C_{0}-C_{e q}\right)}{m} V
$$

where:

$q$ is the quantity of adsorbed metal $\left(\mathrm{mg} \mathrm{g}^{-1}\right)$,

$\mathrm{m}$ is the mass of adsorbent used $(\mathrm{g})$,

$C_{o}$ is the initial concentration of the solution $\left(\mathrm{mg} \mathrm{L}^{-1}\right)$,

$C_{e q}$ is the equilibrium concentration of the metal in the solution $\left(\mathrm{mg} \mathrm{L}^{-1}\right)$ and

$V$ is the volume of the solution (L). 2012).

The percentage removal $(\% R$ ) was calculated according to Equation 2 (Salvado et al.,

$$
\% R=100-\left(\frac{C_{e q}}{C_{0}} 100\right)
$$

where:

$\% R$ is the percentage of $\mathrm{Cd}$ metal removed by natural sponge (\%),

$C_{e q}$ is the equilibrium concentration of the metal in the solution $\left(\mathrm{mg} \mathrm{L}^{-1}\right)$ and

$C_{o}$ is the initial concentration of the solution $\left(\mathrm{mg} \mathrm{L}^{-1}\right.$.)

Equation 3 refers to linearized mathematical models of Langmuir (Witek-Kroviak et al., 2011).

$$
\frac{C_{e q}}{q}=\frac{1}{q_{m} b}+\frac{C_{e q}}{q_{m}}
$$

where:

$C_{e q}$ is the equilibrium concentration $\left(\mathrm{mg} \mathrm{L}^{-1}\right)$;

$q$ is the amount of adsorbed metal $\left(\mathrm{mg} \mathrm{g}^{-1}\right)$;

qm the maximum adsorption capacity $\left(\mathrm{mg} \mathrm{g}^{-1}\right)$ and

$b$ is a parameter of the Langmuir isotherm associated with the adsorbent-adsorbate interaction forces. Equation 4 refers to the Freundlich isotherm (Witek-Kroviak et al., 2011).

$$
\log q=\log K_{f}+\left(\frac{1}{n}\right) \log C_{e q}
$$

where:

$C_{e q}$ is the equilibrium concentration $\left(\mathrm{mg} \mathrm{L}^{-1}\right)$; 
$q$ is the equilibrium amount adsorbed per unit mass of adsorbent $\left(\mathrm{mg} \mathrm{g}^{-1}\right)$;

$K_{f}$ and $n$ are both parameters of the Freundlich isotherm, in which $K_{f}$ is related to adsorption capacity of heterogeneous solids, and the parameter $n$ with value between 1 and 10 indicates favorable adsorption.

The influence of temperature and the determination of the thermodynamic parameters, enthalpy $(\Delta \mathrm{H})$, entropy $(\Delta \mathrm{S})$ and Gibbs free energy $(\Delta \mathrm{G})$ in the adsorptive process were assessed at $10,20,30,40$ and $50{ }^{\circ} \mathrm{C}$.

A volume of $25 \mathrm{~mL}$ of $25 \mathrm{mg} \mathrm{L}^{-1} \mathrm{Cd}$ was stirred for $30 \mathrm{~min}$ with $500 \mathrm{mg}$ of sponge in a jacketed glass cell. To control the temperatures, a refrigerated bath was used, Solab brand, accurate to $\pm 1{ }^{\circ} \mathrm{C}$, and supernatant samples were collected for determination of $\mathrm{Cd}$ by AAS/flame.

$\Delta \mathrm{H}$ values were found by the slope of the curve $\ln k d \times \frac{1}{T}$ based on the Van't Hoff equation (Equation 5), while $\Delta \mathrm{G}$ and $\Delta \mathrm{S}$ were determined by Equations 6 and 7 .

$$
\begin{aligned}
& \frac{d \ln k}{d T}=\frac{\Delta H^{0}}{R T^{2}} \\
& \Delta G=-R T \ln K d \\
& \Delta G=\Delta H-T \Delta S
\end{aligned}
$$

where:

$K d$ is the distribution coefficient of the adsorbate $\left(\mathrm{L} \mathrm{g}^{-1}\right)$, which represents the ratio between $C_{e q}$ and $q$;

$R$ is the universal gas constant $\left(8.314 \mathrm{~J} \mathrm{~K}^{-1} \mathrm{~mol}^{-1}\right)$ and

$T$ is the temperature expressed in Kelvin (K) (Chakravarty et al., 2008).

Ground sponge $\left(2.0 \mathrm{~g}\right.$ ) was added to a $25 \mathrm{~mL}$ burette and $50 \mathrm{~mL}$ of $\mathrm{Cd} 25 \mathrm{mg} \mathrm{L}^{-1}$ at $\mathrm{pH} 2$, 4, 5 and 6 were percolated under gravity effect with flow rate of $2.5 \mathrm{~mL} \mathrm{~min}^{-1}$ at $25{ }^{\circ} \mathrm{C}$. The concentration of cadmium before and after the percolation was determined by AAS (Flame).

After percolation, the sponge was kept in the burette and $50 \mathrm{~mL} 0.1 \mathrm{~mol} \mathrm{~L}^{-1} \mathrm{HCl}$ solution (Vetec 37\%) was percolated and the percentage of desorption $(\% D)$ of $\mathrm{Cd}$ ions was calculated using Equation 8 (Butter et al., 1998).

$$
\% D=\left(\frac{C_{e q(\text { des. })}}{C_{e q(a d s .)}}\right) \times 100
$$

where:

$C_{e q \text { (des.) }}$ is the amount of desorbed ions in $\mathrm{mg}$ of $\mathrm{Cd}$ and

$C_{e q \text { (ads.) }}$ is the amount of ions adsorbed in $\mathrm{mg}$.

After the aforementioned investigations, the effluent from the laboratory analysis was treated by percolation using vegetable sponge.

\section{RESULTS AND DISCUSSION}

The characterization of the adsorbent material by SEM can be seen in Figure 1, illustrating the fibrous nature and irregular structure found in vegetable sponge which facilitates the adsorption of metal ions. 




Figure 1. Scanning Electron Microscopy of $L$. cylindrica fibers magnified 2.400 times.

Figure 2 shows the difference in the absorption bands of the functional groups in the infrared spectrum with and without $\mathrm{Cd}$ strong band at $3432 \mathrm{~cm}^{-1}$ corresponding to the stretching vibration of the $\mathrm{OH}$ bond of cellulose (carbons 2, 3 and 6 glucose).

A weak band at $2920 \mathrm{~cm}^{-1}$ refers to the deformation in an axial $\mathrm{CH}$ methylene $\left(\mathrm{CH}_{2}\right)$ and peak axial deformation of the carboxyl $\mathrm{C}=\mathrm{O}$ bond, which may be amide groups or carboxylic groups, at $1656 \mathrm{~cm}^{-1}$, acetal group (carbonyl of aldoses). The CO stretching peak at $1743 \mathrm{~cm}^{-1}$ suggests the angular deformation in the plane (Silverstein and Webster, 2000; D'Almeida et al., 2005), a characteristic of compounds with ester groups and carboxyl.

The intensity of the band at $1743 \mathrm{~cm}^{-1}(\mathrm{C}=\mathrm{O}$ acetal) was different in the cadmium sponge with and without $\mathrm{Cd}$ adsorbed on its surface. The band in $1062 \mathrm{~cm}^{-1}$ refers to $\mathrm{C}-\mathrm{OH}$ stretching of the primary alcohol in typical polysaccharides.



Figure 2. FTIR spectrum of the L. cylindrica fibers. a) without adsorbed $\mathrm{Cd}$. b) with adsorbed $\mathrm{Cd}$.

It is of great importance to identify functional groups present in the adsorptive material to observe the formation of complexes between the metal ions and the functional groups contained in the material by means of electrostatic interaction (Ngah and Hanafiah, 2008). 
In Table 1, shows the amount of Cd removed at different times by stirring at $\mathrm{pH} 2.0,4.0$, 5.0 and 6.0. After 25 minutes, the adsorbed amount of cadmium was not significantly different between $\mathrm{pH} 4.0$ and $\mathrm{pH} 6.0$, indicating that the process can be carried out in this $\mathrm{pH}$ range. The stirring time 20 minutes was sufficient to remove $89.6 \%$ of $\mathrm{Cd}$ at $\mathrm{pH} 5.0$ as shown in Table 1 . The stirring time around 20 minutes was sufficient for binding sites to be available for adsorption of $\mathrm{Cd}$, arranging the active sites into layers on the surface of the adsorbent.

Table 1. Removal of $\mathrm{Cd}$ for different times of stirring and different $\mathrm{pH}$.

\begin{tabular}{ccc}
\hline $\mathbf{p H}$ & Stirring Time (min.) & $\mathbf{R}(\%)$ \\
\hline 2 & & 60.8 \\
4 & 10 & 77.2 \\
5 & & 83.6 \\
6 & & 85.2 \\
\hline 2 & 20 & 58.0 \\
4 & & 81.2 \\
5 & & 89.6 \\
6 & & 85.2 \\
\hline 2 & 30 & 56.8 \\
4 & & 80.0 \\
5 & & 72.4 \\
6 & & 87.6 \\
\hline 2 & \multirow{3}{*}{40} & 57.6 \\
4 & & 84.0 \\
5 & & 81.6 \\
6 & & 81.6 \\
\hline 2 & & 55.3 \\
4 & 50 & 86.8 \\
5 & & 84.0 \\
6 & & 89.0 \\
\hline
\end{tabular}

Low $\mathrm{pH}$ (acidic) results in protonation of the active sites of the adsorbent material causing a competition between cations and metal ions for sorption sites (Salvado et al., 2012; Tobin et al., 1984; Gardea-Torresdey et al., 2005).

However, under alkaline $\mathrm{pH}$ values, formation of complex hydroxides, carbonates and organic complexes lowers the availability of metal ions for the sorption on adsorptive materials. Another important factor is that extreme $\mathrm{pH}$ values can damage the structure of the adsorbent material, causing cellular distortion and significant mass loss.

In this way, the $\mathrm{pH}$ of the solution is a critical parameter because it controls the adsorption at the solution-biomass interface and the speciation of metal ions. It is necessary to consider the ionic functional groups of the biosorbent and the metal species at different $\mathrm{pH}$ values (Farroq et al., 2011).

Numerous models of adsorption isotherms are known, but the most commonly accepted and used for applications in water and wastewater treatment are the Freundlich and Langmuir models. Table 2 shows the experimental results for the adsorption of $\mathrm{Cd}$. 
Table 2. Studies on Cd adsorption at $\mathrm{pH}$ 5.0.

\begin{tabular}{cccccc}
\hline & $\begin{array}{c}\mathbf{M} \\
(\mathrm{g})\end{array}$ & $\begin{array}{c}\mathbf{C}_{\mathbf{0}} \\
\left(\mathrm{mg} \mathrm{L}^{-1}\right)\end{array}$ & $\begin{array}{c}\mathbf{C}_{\mathbf{e q}} \\
\left(\mathrm{mg} \mathrm{L}^{-1}\right)\end{array}$ & $\begin{array}{c}\mathbf{Q} \\
\left(\mathrm{mg} \mathrm{g}^{-1}\right)\end{array}$ & $\begin{array}{c}\mathbf{R} \\
(\%)\end{array}$ \\
\hline 1 & 0.5043 & 10 & 0.93 & 0.90 & 90.70 \\
2 & 0.5015 & 20 & 1.65 & 1.83 & 91.75 \\
3 & 0.5066 & 30 & 2.88 & 2.68 & 90.40 \\
4 & 0.5057 & 40 & 4.00 & 3.56 & 90.00 \\
5 & 0.5024 & 50 & 5.37 & 4.44 & 89.26 \\
6 & 0.5015 & 60 & 6.48 & 5.34 & 89.20 \\
7 & 0.5021 & 70 & 9.02 & 6.07 & 87.11 \\
8 & 0.5060 & 80 & 9.87 & 6.93 & 87.66 \\
9 & 0.5036 & 90 & 11.77 & 7.77 & 86.92 \\
\hline
\end{tabular}

The small difference between the coefficient of determination $\left(R^{2}\right)$ after the linearization of Langmuir and Freundlich isotherms indicates that adsorption possibly occurs at "mono" and "multi" layers (Gonçalves Junior et al., 2012). However, best results are explained by the Freundlich isotherm, wherein $R^{2}$ is higher than the Langmuir as shown in Table 3, which presents isotherm parameters.

Table 3. Parameters of equilibrium isotherms of Langmuir and Freundlich' models.

\begin{tabular}{ccc|ccc}
\hline \multicolumn{2}{c|}{ Langmuir } & \multicolumn{3}{c}{ Freundlich } \\
\hline $\mathbf{q}_{\mathbf{m}}\left(\mathrm{mg} \mathrm{g}^{-1}\right)$ & $\mathbf{b}$ or $\mathbf{K}_{\mathbf{L}}\left(\mathrm{L} \mathrm{mg}^{-1}\right)$ & $\mathbf{R}^{2}$ & $\mathbf{k}_{\mathbf{f}}\left(\mathrm{mg} \mathrm{g}^{-1}\right)$ & $\mathbf{n}$ & $\mathbf{R}^{2}$ \\
18.450 & 0.060 & 0.914 & 1.086 & 1.221 & 0.984 \\
\hline
\end{tabular}

The value of $\mathrm{n}$ (the reactivity of exchange sites) greater than 1 indicates that the adsorption is favorable and the sites are highly energetic with high maximum adsorption capacity (18.450 mg Cd per gram of sponge, which corresponds to $1.641 \times 10^{-4} \mathrm{~mol}$ of $\mathrm{Cd}$ ). The average rate of removal of $\mathrm{Cd}$ was $89.2 \%$.

For a better interpretation of the experimental data, the linearized model of Freundlich isotherm $\left(\mathrm{R}^{2}=0.984\right)$ was employed.

The negative value for the enthalpy $\left(\Delta H=-10.26 \mathrm{~kJ} \mathrm{~mol}^{-1}\right)$ means that the adsorption is exothermic. Entropy $(\Delta S)$ had a value greater than zero $\left(7.51 \mathrm{~kJ} \mathrm{~mol}^{-1}\right)$, pointing to an increase in disorder at the interface of solid-solution, indicating spontaneous adsorption and that the process showed greater randomness (Salvado et al., 2012).

The system is spontaneous and the interaction between the adsorbent and adsorbate is favorable, with a calculated value of Gibbs free energy $(\Delta G)$ of $-12.50 \mathrm{~kJ} \mathrm{~mol}^{-1}$.

Large-scale fixed-bed column systems are a practical alternative to adsorb organic compounds in aqueous solutions. In addition to evaluating the removal and recovery of these compounds under dynamic flow conditions, such experiments allow us to test the ability of packed columns with recycling of biomass, which may be fresh or immobilized (Gardea-Torresdey, 2005). Immobilization, however, is of utmost importance, since very small particles of biomass obstruct the flow through the column. The removal of $\mathrm{Cd}$ using the percolation method at different $\mathrm{pH}$ shows removal between 99.52 and $99.80 \%$ in 30 minutes at $\mathrm{pH} 2.0$ to 6.0 . 
Compared with the stirring method, the percolating method is more effective and shows better results. It is observed that the rate of removal of $\mathrm{Cd}$ by percolation, independent of $\mathrm{pH}$ in the range between 2.0 and 6.0 .

When using $2.0 \mathrm{~g}$ sponge in the percolation, a final Cd concentration of $0.16 \mathrm{mg} \mathrm{L}^{-1}$ is obtained in the effluent. In the case of desorption, the final Cd concentration was $0.02 \mathrm{mg} \mathrm{L}^{-1}$.

According to Resolution 430/2011 of National Council for the Environment (Brasil, 2011), partially amending the Resolution 357/2005, the maximum permissible cadmium concentration for effluent discharge is $0.2 \mathrm{mg} \mathrm{L}^{-1}$. When compared to the final values of $\mathrm{Cd}$ after adsorption, it is concluded that the values are below the maximum allowed by Brazilian laws, indicating that the adsorbent performs excellently in the removal of the metal. The maximum contaminant level for cadmium in effluent is $0.005 \mathrm{mg} \mathrm{L}^{-1}$ for USEPA parameters (USEPA, 2013), indicating that the proposed method is also feasible to meet this legislation using higher amount of adsorbent.

The results demonstrate that the average desorption is $9 \%$, that is, the adsorption $(99.36 \%$ retention) of the metal species occurs irreversibly indicating that the material has more interaction with the metal under study (Salvado et al., 2012), facilitating its removal from the environment.

Since the material is easy to obtain and inexpensive there is no need for it to be reused in further stages of adsorption. After its use, the sponge residue can be dried and embedded in concrete blocks to not contaminate the environment, or incinerated in environmentally friendly furnaces to recover metals.

The removal of cadmium from the laboratory effluent was $18.8 \%$, and since the waste contains mercury $(\mathrm{Hg})$, there may be competition for the active sites of the sponge, probably due to higher electronegativity of $\mathrm{Hg}$ (2.00) compared to $\mathrm{Cd}$ (1.69), a hydrate ion of similar size (500 picometers) and chemical similarity (Kielland, 1937).

\section{CONCLUSION}

L. cylindrica is a natural and inexpensive material, easily obtained, with a high retention rate of $\mathrm{Cd}$ ions on its surface $(99.80 \%)$ at $\mathrm{pH} 5.0$ when percolated and $89.6 \%$ when mechanically stirred. It is noteworthy that the natural sponge adsorbs significant amounts of $\mathrm{Cd}$ in the range of $\mathrm{pH} 4.0$ to 6.0 , indicating that it is not necessary to adjust $\mathrm{pH}$ for most treatments in real samples.

The $\mathrm{Cd}$ ion is spontaneous and favorably adsorbed by natural sponge, according to the Freundlich isotherm model. The high adsorption rate indicates the feasibility of using this biomass in the remediation of contaminated environments. This work demonstrates the possibility of using L. cylindrica fibers for industrial wastewater treatment, highlighting its advantageous features: it is an economical, natural fiber that is non-toxic and biodegradable.

\section{ACKNOWLEDGMENT}

The authors thank Prof. Cesar Tarley (UEL) for measurements by SEM and FTIR.

\section{REFERENCES}

ALTINISIK, A.; GUER, E.; SEKI, Y. Natural sorbent Luffa cylindrica for the removal of a model basic dye. Journal of Hazardous Materials, v. 179, p. 658-664, 2010. http://dx.doi.org/10.1016/j.jhazmat.2010.03.053 
ARRUDA, M. A. Z.; TARLEY, C. R. T. Natural adsorbents: potential and applications of natural sponge (Luffa cylindrica) in lead removal in wastewater laboratory. Analytica, v. 04, p. 25-31, 2003.

BRASIL. Conselho Nacional do Meio Ambiente - CONAMA. Resolução no 357, de 17 março de 2005. Diário Oficial [da] União, Brasília, DF, 18 mar. 2005, p. 58.

BRASIL. Conselho Nacional do Meio Ambiente - CONAMA. Resolução no 430, de 13 maio 2011. Diário Oficial [da] União, Brasília, DF, 16 maio 2011, p. 89.

BUTTER, T. J.; EVISON, L. M.; HANCOCK, I. C.; HOLLAND, F. S.; MATIS, K. A.; PHILIPSON, A. et al. I. The removal and recovery of cadmium from dilute aqueous solutions by biosorption and electrolysis at laboratory scale. Water Research, v. 32, p. 400-406, 1998. http://dx.doi.org/10.1016/S0043-1354(97)00273-X

CHAKRAVARTY, S.; PIMPle, S.; CHATURVEDI, H. T.; SINGH, S.; GUPTA, K. K. Removal of copper from aqueous solution using newspaper pulp as an adsorbent. $\begin{array}{lllllll}\text { Journal of Hazardous } & \text { Materials, v. 159, p. 396-403, } 2008 .\end{array}$ http://dx.doi.org/10.1016/j.jhazmat.2008.02.030

D'AlMEIDA, A. L. F. S.; CALADO, V.; BARRETO, D. W.; D'AlMEIDA, J. R. M. Acetylation of Fiber Bushing (Luffa cylindrica). Polímeros, v. 15, p. 59-62, 2005.

DEMIR, H.; TOP, A.; BALKOSE, D.; ULKU, S. Dye adsorption behavior of Luffa cylindrica fibers. Journal of Hazardous Materials, v. 153, p. 389-394, 2008. http://dx.doi.org/10.1016/j.jhazmat.2007.08.070

FARROQ, U.; KHAN, M. A.; ATHAR, M.; KOZINKI, J. A. Effect of modification of environmentally friendly biosorbent wheat (Triticum aestivum) on the biosorptive removal of cadmium (II) ions from aqueous solution. Chemical Engineering Journal, v. 171, p. 400-410, 2011. http://dx.doi.org/10.1016/j.cej.2011.03.094

GARDEA-TORRESDEY, J. L.; DE LA ROSA, G.; PERALTA-VIDEA, J. R.; MONTES, M.; CRUZ-JIMENEZ, G.; CANO-AGUILERA, I. Differential uptake and transport of trivalent and hexavalent chromium by tumbleweed (Salsola kali). Archives of Environmental Contamination and Toxicology, v. 48, p. 225-232, 2005. http://dx.doi.org/10.1007/s00244-003-0162-X

GONÇALVES JUNIOR, A. C.; STREY, L.; LINDINO, C. A.; NACKE, H.; SCHWANTES, D.; SEIDEL, E. P. Applicability of the Pinus bark (Pinus elliottii) for the adsorption of toxic potentially toxic metals from aqueous solutions. Acta Scientiarum, Technology, v. 34, p. 79-87, 2012.

HENINI, G.; LAIDANI, Y.; SOUAHI, F.; HANINI, S. Study of static adsorption system phenol/Luffa cylindrica fiber for industrial treatment of wastewater. Energy Procedia, v. 18, p. 395-403, 2012. http://dx.doi.org/10.1016/j.egypro.2012.05.051

KIELLAND, J. Individual activity coefficients of ions in aqueous solutions. Journal of American Chemical Society, v. 59, p. 1675-1678, 1937.

http://dx.doi.org/10.1021/ja01288a032 
LAIDANI, Y.; HANINI, S.; HENINI, G. Use of fiber Luffa cylindrica for waters treatment charged in copper. Study of the possibility of its regeneration by desorption chemical. Impact of integrated clean energy on the future of the Mediterranean environment. Energy Procedia, v. 6, p. 381-388, 2011.

http://dx.doi.org/10.1016/j.egypro.2011.05.044

MONTEIRO, L. P. C.; MAINIER, F. B. Evaluation of using steel wires and sponges and removal of copper in industrial effluents. Engevista, v. 12, p. 33-40, 2010.

NGAH, W. S. W.; HANAFIAH, M. A. K. M. Removal of heavy metal ions from wastewater by chemically modified plant wastes as adsorbents: a review. Bioresourses Technolog, v. 99, p. 3935-3948, 2008. http://dx.doi.org/10.1016/j.biortech.2007.06.011

OLIVEIRA, E. A.; MONTANHER, S. F.; ROLLEMBERG, M. C. Removal of textile dyes by sorption on low-cost sorbents. A case study: sorption of reactive dyes onto Luffa cylindrica. Desalination and Water Treatment, v. 25, p. 54-64, 2011. http://dx.doi.org/10.5004/dwt.2011.1416

PRADO, A. G. S. Green chemistry, chemical challenges of the new millennium. Química Nova, v. 26, p. 738-744, 2003. http://dx.doi.org/10.1590/S0100-40422003000500018

RIBEIRO, A. V. F. N.; BELISARIO, M.; GALAZZI, R. M.; BALTHAZAR, D. C.; PEREIRA, M. de G.; RIBEIRO, J. N. Evaluation of two bioadsorbents for removing paracetamol from aqueous media. Electronic Journal of Biotechnology, v. 14, n. 6, 2011. http://dx.doi.org/10.2225/vol14-issue6-fulltext-8

RODRIGUES, R. F.; TREVENZOLI, R. L.; SANTOS, L. R. G.; LEÃO, V. A.; BOYTARO, V. R. Adsorption of potentially toxic metals on sawdust treated with citric acid. Engenharia Sanitária e Ambiental, v. 11, p. 21-26, 2006.

SALEHIZADEH, H.; SHOJAOSADATI, S. A. Removal of metals ions from aqueous solution by polysaccharide produced from Bacillus firmus. Water Research, v. 37, p. 4231-4235, 2003. http://dx.doi.org/10.1016/S0043-1354(03)00418-4

SALVADO, A. P. A.; CAMPANHOLI, L. B.; FONSECA, J. M.; TARLEY, C. R. T.; CAETANO, J.; DRAGUNSKI, D. C. Lead (II) adsorption by peach palm waste. Desalination and Water Treatment, v. 48, p. 335-343, 2012. http://dx.doi.org/10.1080/19443994.2012.698839

SILVERSTEIN, R. M.; WEBSTER, F. X. Spectrometric identification of organic compounds. 6. ed. Rio de Janeiro: LTC, 2000.

TAGLIAFERRO, G. V.; PEREIRA, P. H. F.; RODRIGUES, L. A.; PINTO DA SILVA, M. L. C. Cadmium, lead and silver adsorptio in hydrous niobium oxide prepared by homogeneous solution method.. Química Nova, v. 34, p. 101-105, 2011. http://dx.doi.org/10.1590/S0100-40422011000100020

TANOBE, V. O. A.; TORQUATO, L. P.; AMICO, S. C.; SYNDENSTRICKER, T. H. D. Influencia dos tratamentos químicos nas propriedades físico-químicas de esponjas de Luffa cilíndrica. In: CONGRESSO BRASILEIRO DE ENGENHARIA E CIÊNCIAS DOS MATERIAIS. 15., 9-13 nov. 2002, Natal. Anais... 2002. [S.1.]: UNESP, 2002. p. 1602-1607. 1 CD-ROM. 
TOBIN, J. M.; COOPER, D. G.; NEUFELD, R. J. Uptake of metal ions by Rhizopus arrhizus Biomass. Applied Environmental Microbiology, v. 47, p. 821-824, 1984.

TRAN, H. H.; RODDICK, F. A.; O'DONNELL, F. A. Comparison of chromatography and desiccant silica gels for the adsorption of metal ions-I. adsorption and kinetics. Water Research, v. 33, p. 2992-3000, 1999. http://dx.doi.org/10.1016/S0043-1354(99)00017-2

UNITED STATES. Environmental Protection Agency - USEPA. National primary drinking water regulations. EPA 816-F-09-0004, May 2009. Available in: http://water.epa.gov/drink/contaminants/basicinformation/alachlor.cfm. Accessed: Aug. 21, 2012.

UNITED STATES. Environmental Protection Agency - USEPA. Wastewater treatment plant. July 2013. Available in:

http://www.epa.gov/region10/pdf/permits/npdes/id /HARSB_FS.pdf. Accessed: April 02, 2014.

VOLESKY, B. Detoxification of metal-bearing effluents: biosorption for the next century. Hydrometallurgy, v. 59, p. 203-206, 2001. http://dx.doi.org/10.1016/S0304386X(00)00160-2

YE, C.; HU, N.; WANG, Z. Experimental investigation of Luffa cyllindrica as a natural sorbent material for the removal of a cationic surfactant. Journal of the Taiwan Institute of Chemical Engineers, v. 44, p. 74-80, 2013.

WELZ, B.; SPERLING, M. Atomic absorption spectrometry. $2^{\text {nd }}$ ed. Weinheim: WileyVCH, 1999.

WITEK-KROWIAK, A.; SZAFRAN, R. G.; MODELSKI, S. Biosorption of potentially toxic metals from aqueous solutions onto peanut shell as a low-cost biosorbent. Desalination, v. 265, p. 126-134, 2011. http://dx.doi.org/10.1016/j.desal.2010.07.042 